\title{
Hellenic Integrative Psychotherapy: A Total Holistic Approach
}

\author{
Joannis N. Nestoros ${ }^{1,2}$ \\ ${ }^{1}$ University of Crete, Heraklion and Rethymnon, Greece \\ ${ }^{2}$ Synchronal Amphiaraia Spin-Off Company, Athens, Greece \\ Email:info@amphiaraia.com
}

How to cite this paper: Nestoros, J. N. (2018). Hellenic Integrative Psychotherapy: A Total Holistic Approach. Psychology, 9, 1731-1760.

https://doi.org/10.4236/psych.2018.97103

Received: May 31, 2018

Accepted: July 9, 2018

Published: July 12, 2018

Copyright (c) 2018 by author and Scientific Research Publishing Inc. This work is licensed under the Creative Commons Attribution International License (CC BY 4.0).

http://creativecommons.org/licenses/by/4.0/

\begin{abstract}
An integrative psychotherapy model is described which proposes that the basic "schools" of psychotherapy, that is the psychodynamic, behavioral, humanistic/existential, systemic and biological approaches can be synthesized into a new improved paradigm. This total holistic approach is not in conflict with any of the contributing models which are perceived as complementary to each other. Moreover, there is ample scientific evidence that all traditional psychotherapies share the same common therapeutic factors. Hellenic integrative psychotherapy comprises a new idealistic approach which has different improved properties in the same way that Water differs from its constituents Oxygen and Hydrogen. Elements of ancient Greek philosophy, mythology, history, literature, ethics, values, reasoning, mentality and way of life are considered to be an important constituent of Hellenic Integrative Psychotherapy. Hippocratic diet, Bodily exercises that enhance physical wellness and brain function, Therapeutic thermal and cold baths, Thalassotherapy, Exposure to sunlight, Music therapy, Theater therapy, Art therapy, Therapeutic architecture and the exposure to a Therapeutically beautiful physical environment constitute important integral elements of the presented total holistic approach. Last but not least, Neurofeedback (training of the EEG) and Event Related Potentials (ERPs) will be employed.
\end{abstract}

\section{Keywords}

Integrative Psychotherapy, Pharmacotherapy, Hippocratic Diet, Physical Exercise, Therapeutic Physical Environment, Therapeutic Architecture, Therapeutic Greek Philosophy and Culture, Neurofeedback

\section{Introduction}

Nowadays, there are over a thousand different psychotherapy approaches, some 
representing minor variations of others and/or the employment of the same principles using a different terminology, while others are based on entirely different conceptualizations of human nature, psychology personality theory, psychopathology, psychotherapeutic processes and ethics and/or proposed ways of living in order to achieve ideal self-awareness and self-development. Most psychotherapies involve one-to-one sessions, between client and therapist, yet often psychotherapies are conducted with groups. Family therapy and Couple therapy are also quite common. Psychotherapists are mental health professionals from a very wide spectrum of backgrounds, such as psychiatry, psychology and clinical social work. Yet many other professionals with background in education, sociology, economics or even without any kind of University degree practice psychotherapy by naming it "Counseling of Mental Health" or "Personal Training". Depending on the jurisdiction of every different country, psychotherapists may be legally regulated, voluntarily regulated or completely unregulated, since the term "Psychotherapist" is usually not protected or even well defined.

To quote Norcross (2005: p. 3) who of course is referring to recent post-Freudian times: "Rivalry among theoretical orientations has a long and undistinguishing history in psychotherapy, dating back to Freud. In the infancy of the field, therapy systems, like battling siblings competed for attention in a 'dogma eat dogma' environment (Larson, 1980). Clinicians traditionally operated from within their own particular frameworks, often to the point of being blind to alternative conceptualizations and potentially superior interventions. Mutual antipathy and exchange of puerile insults between adherents of rival orientations were very much the order of the day". Yet, even in the 1950's certain studies supported that favorable therapeutic results in the clients were less influenced by the theoretical orientation of the therapist and were more determined by the experience and personality characteristics of their therapist (Feidler, 1950; Heine, 1953). At about the same time Judd Marmor, Franz Alexander and their collaborators systematically studied the above findings by detailed recording through a one-way mirror of the psychotherapeutic interactions of clients with therapists who were all psychoanalysts, yet they adhered to different theoretical orientations (orthodox supporters of Sigmund Freud; schismatic supporters of Alfred Adler, Carl G. Jung and Otto Rank; and Neo-Freudian supporters of Harry Stack Sullivan etc.). The therapeutic results were similar regardless of the therapists' conviction that the patient became better because of each "different particularly correct interpretation" of their behavior. Judd Marmor in a series of papers tried to find an explanation to this incomprehensible at the time finding. He concluded that Psychoanalytic Therapy is an Educational Process (Marmor, 1962, 1964, 1966), thus creating the first evidence-based bridge between Psychodynamic Therapies and Learning Theories and /or Behavioral Therapy. It is interesting that Thomas French addressing the Annual Meeting of the American Psychiatric Association in 1932 drew certain parallels which exist between Psychoanalysis and Pavlovian Conditioning (French, 1933). Furthermore, Judd Marmor in his Academic Lec- 
ture addressing the Canadian Psychiatric Association annual meeting in 1974 said the following: "...perhaps one of these days we shall see an end to the partisan and passionate proclamations of the superiority of one technique over all others, and to be able to devote ourselves to the more fundamental and more promising task of developing a unified science of psychotherapy..." (Marmor, 1975: p. 565). The ever increasing recognition in the 1970s of the value of other therapeutic orientations culminated in the integration movement of the 1980s (Castonguay \& Goldfried, 1994).

The integration movement aspires to unite diverse models and techniques beyond the boundaries of traditional single-school orientations, thus succeeding in a better understanding and improvement of psychotherapy by combining the perspectives of the different approaches (Arkowitz, 1992). This trend appears to be gaining momentum and is likely to be the Zeitgeist of the next several decades of psychotherapy practice and research (Beitman et al., 1989). Integrationists have not sought to reach a unique and totally new set of paradigms that would explain psychodynamic processes, such as the resolution of Oedipal complexes, learning mechanisms, such as operant conditioning, or humanistic/existential concepts, such as the actualization tendency (Castonguay \& Goldfried, 1994). On the contrary, their main purpose is to explore more valid than the preexisting conceptualizations of human behaviors and to suggest more effective interventions.

The milestones in the history of psychotherapy integration can be found in detail in Hawkins \& Nestoros, 1997 (pp. 67-77) and in Nestoros (2012a: pp. 113-138). From this account, the conclusions of Beitman et al. (1989) that rapprochement constitutes an earlier developmental stage than mature theoretical integration is affirmed. Moreover, it is worthwhile to examine the factors which have recently begun to foster the psychotherapy integration movement, which vary in different publications from five (Beitman et al., 1989) to eight (Norcross \& Newman, 1992). In our review of the literature (Beitman et al., 1989; Castonguay \& Goldfried, 1994; Goldfried \& Newman, 1986; London, 1983, 1988; Norcross, 1986a; Norcross \& Grencavage, 1989; Norcross \& Newman, 1992), these factors, which are mutually reinforcing, were classified as follows: 1) Proliferation of psychotherapies and socio-economic contingencies, 2) Inadequacy of single theories, 3) Complementary nature of different orientations, 4) Convergence, 5). Equality of outcomes among therapies, 6) Commonalities among therapies and 7) Emphasis on personal characteristics and therapeutic relationship.

The most recent edition of the Handbook of Psychotherapy Integration (Norcross \& Goldfried, 2005) recognized four general routes to integration: Common Factors, Technical Eclecticism, Theoretical Integration, and Assimilative Integration (Norcross, 2005). The "Hellenic Integrative Psychotherapy: A total holistic approach" model which is presented in this article adheres to the "Common Factors" and into a most optimistic and idealistic attempt of "Theoretical Integration of everything with everything", which is not limited only to psychotherapeutic approaches. It also synthesizes Psychopharmacology, Hippocratic diet, 
Physical exercise, Therapeutic physical environment, Therapeutic Architecture, Therapeutic Greek philosophy and culture, Neurofeedback and Event Related Potentials.

The model presented here was influenced by the following: a) My training in psychotherapy at McGill (1973-1977) fostered an "eclectic" approach to psychotherapy, offering experience and supervision in the psychoanalytic, behavioral and Rogerian approaches, in a system accepting every possible combination of the above in the form of individual, couple, family and group therapy, administered alone or in various mixtures on a short term or long term basis; b) The international and multicultural atmosphere of the McGill diploma in psychiatry program (for example my supervisors came to Montreal from 11 different countries and practiced four different religions: Christian, Hebrew, Hindu and Muslim) encouraged a multifaceted approach to problems; c) My research experience with the eminent psychopharmacologists Heinz E. Lehmann, Thomas A. Ban, J. Ananth, N.P.V Nair and G. Chouinard removed all prejudices against medications common among other psychotherapists; d) McGill's Department of Psychiatry encouraged collaboration between basic and clinical scientists (see Sourkes \& Pinard, 1994) resulted in my substantial research experience in basic neuroscience with K. Krnjevic. Apart from teaching me his motto, "Research is Fun", K. Krnjevic gave me an appreciation of how the brain works and an approach to psychotherapy which attempts to integrate to our clinical experience what we know from the various basic neurosciences; e) The possibility to attend lectures by eminent scientists at the Departments of Psychiatry, Neurology and Neurosurgery (at the Montreal Neurological Institute and Hospital), Psychology, Physiology, Pharmacology, etc., showed me the advantages of looking at things from the view point of different perspectives and through different methodologies and techniques; f) listening to Judd Marmor's academic lecture at the 1974 annual meeting of the Canadian Psychiatric Association (see Marmor, 1975) on Psychotherapy; g) Needless to say that my personal psychotherapy with Lela C. Korenberg (my intellectual Mother) was by far the most important force shaping my views on psychotherapy in general. It is beyond the scope of this article to describe in detail what happened during that therapy and what I have learned intellectually and emotionally.

Nevertheless, I summarize some of the basic principles of her approach which I am utilizing in the model presented here: 1) The central role of fear in all psychological disorders; 2) The important role of emotional support in all psychotherapies; 3) Never to accept anything (concept, theory, etc.) if it doesn't make sense to you and if there is no scientific evidence for it, regardless of the prestige associated with the person proposing it; and of course regardless of its popularity among other scientists; 4) Always look for simple rather than complicated explanations; 5) The explanations for the phenomena in clinical practice and in psychotherapy come from a variety of related fields (Psychology, Psychiatry, Neurosciences, Sociology, Anthropology, Ethology, Philosophy, etc.) and one has to be able to understand and integrate all of these in order to be helpful to 
his client; 6) What the person in psychotherapy consciously wants is by far the most important factor in psychotherapy, although the therapist's personality and attitude towards his client as well as the therapist's training are also crucial; 7) One can offer insight-oriented psychotherapy and supportive psychotherapy at the same time.

\section{Common Factors in All Psychotherapies}

\section{1) Therapeutic relationship.}

The therapeutic relationship is by far the most important common factor in all psychotherapies (Horvath et al., 2011). The patient considers the therapist as an important person. Often, this same specialist has helped a relative or a friend of the new client. The therapeutic alliance is positively or negatively influenced by the therapist's social status, his/her appearance (height, weight, clothing, facial expression), office furniture (psychoanalytic couch, face to face therapy, paintings, plants, etc.). The office should be in a quiet place at a distance from noisy toilettes and elevators. The psychotherapeutic session usually lasts $45^{\prime}$ in individual therapy and should not be interrupted by telephone calls or other distractions. We should use whatever means foster the patient's feeling that he will be helped by the therapist. The therapist should emphasize that his relationship with his patient is a professional one and they should avoid fostering any other kind of relationship (business partnership, etc.) among them (Smith, 1980). Many patients and unfortunately quite a few therapists confuse the emotional closeness, which constitutes a very important psychotherapeutic element, with that of sexual attraction. Sexual relations with the patient always worsen his/her psychological problems (Grunebaum, 1986; Sonne et al., 1985). The patient-therapist relationship could be very much influenced by their actual individual characteristics (ingenuity, eloquence, attractiveness, etc.) as well as by the actual life conditions they are in. For instance, the therapist could be upset when he is summoned to court or when one of his loved ones falls ill.

However, some phenomena that have nothing to do with the actual present reality situation but have very much to do with the patients' and therapists' past, also play a very important role. These are the phenomena of transference and counter transference. The patient in psychotherapy improves through and because of his/her relationship with the therapist. Sometimes the patient improves because he wants to please his therapist. If the patient doesn't want to get well or is not ready to improve, it is impossible for him/her to get help by any therapist. This is what Wilhelm Stekel was referring to when he said that the "patient should have the willingness to be cured" (see Marmor et al. 1981). Many times patients do not improve because they are afraid to change. This sometimes happens because change is considered as a rejection of a beloved part of the self, since the patient wrongly believes that changes in his/her life during therapy are imposed by the therapist (Castelnuovo-Tedesco, 1979). Certainly, it must be emphasized and understood that psychotherapy is a voluntary procedure which aims to increase individual freedom. 


\section{2) Anxiety reduction and emotional support.}

This is probably one of the most important processes in psychotherapy. Maybe the most significant aspect of thoughts, as far as mental health is concerned, is the quality and quantity of positive or negative emotions they generate. There are many ways to reduce the patient's anxiety: first of all, when the patient speaks about his/her stressful life events this usually causes anxiety and other negative feelings to his relatives and friends. However, this does not happen when he speaks to his/her therapist. Alexander and French have named this interaction between "transference" and "counter transference" processes "corrective emotional experience" (see Alexander \& French, 1946). They noted that "Freud himself came to the conclusion that in the treatment of some cases, phobias for example, a time arrives when the analyst must encourage the patient to engage in those activities he has avoided in the past" (p. 39). These interactions were later discussed in the light of the learning theory (Alexander, 1963). Secondly, a psychotherapist is able to help people find solutions to problems that he/she has already solved theirselves. It is important that the therapist is calm and able to endure unpleasant affective states generated either in his patients or in himself (Eisen, 1979; Whitfield, 1980). Thirdly, there are specific techniques, especially in the behavioral therapies-particularly using systematic desensitization (Wolpe, 1958) and implosion or flooding therapy (Polin, 1959) - which directly reduce both tension and fear in the patient. Most other approaches to psychotherapy employ, to one degree or another, techniques similar to the aforementioned behavioral procedures. Wachtel (1977) has recommended the use of these techniques in the context of psychodynamic psychotherapy.

When a person is stressed this causes a malfunction in his concentration, memory and attention. Consequently, the reduction of anxiety liberates these important cognitive functions and enables the individual to make use of his/her resources and talents in order to solve their problems.

It must be also emphasized that the alleviation of anxiety causes the reduction or even the elimination of psychopathological symptoms in the majority of psychological disorders. For example, studies have shown that high doses of diazepam can significantly reduce symptoms, even eradicate them, in many paranoid schizophrenic patients. In these experiments the doses used were ten times higher than the doses producing deep sleep or coma in normal or neurotic persons, but, nevertheless, no drowsiness occurred in the doses alleviating schizophrenic symptoms (Nestoros et al., 1982, 1983; Lingjaerde, 1985). Similar reduction in psychopathological symptoms could be attained when the therapist manages to make the patient calm by using purely psychotherapeutic methods and techniques. Therefore, we should always evaluate how the patient functions under the influence and in the presence of the therapist, but also how they behave when they are alone and facing frustrating circumstances.

3) Provision of new cognitive context

Every psychotherapy provides the patient with a new cognitive context which 
enables them to interpret and understand their behavior as well as that of others'. According to Castelnuovo-Tedesco (see Marmor et al., 1981) this goal could succeed with reference to the Oedipus Complex, Karma, the stars, or any other context that the patient can possibly relate to. Jerome Frank (1973) used the term "mythology" to name this system of conviction about principles of human behavior. He also underlined that although this system is different from one therapy to another, it always provides a new explanation of behavior. All types of learning-classical conditioning, operant conditioning, observation and modeling, and cognitive learning-play their role in the development of the new cognitive context in psychotherapy. With the therapist's support, life situations and people are interpreted as less threatening to the patient.

4) Persuasion and suggestion

The persuasion of the therapist about the effectiveness of his therapeutic methods and the suggestion to the patient that therapy will succeed are both major elements in all psychotherapies. Jerome Frank (1973) refers to the "raise of morale" and Marmor et al. (1981) to the "increase of hope" as necessary prerequisites in order to change one's way of thinking and behavioral habits. All agree that the therapist should be confident that their method is effective. The therapist should also communicate to the patient that they care about them and that it is worthy for the patient to invest in the therapeutic relationship. The therapeutic alliance is fostered by certain characteristics of the therapist's personality. Some of these are empathy, warmth and genuineness (Truax \& Carkhuff, 1967). Levis (see Marmor et al., 1981) reports that the ability of the therapist to alternate between two different positions (ego states) within the therapist-patient relationship assists the therapeutic procedure. In the first position, the therapist acts as a distant, objective specialist who observes without intervening. In the second position the therapist has empathy with what is happening to the patient and allows himself to interact freely with the patient.

\section{5) Identification with the therapist}

The identification with the therapist is a common component in all psychotherapies. The experiments of Albert Bandura (Bandura, 1962, 1969, 1973, 1977) have clearly demonstrated the importance of the processes of imitation and identification. Modeling could assist the patient in the following three ways (Bandura, 1969; Paraskevopoulos, 1988):

a) To attain new desirable behavioral modes which are outside of his repertoire,

b) To use existing behavioral modes of his repertoire in a socially effective way,

c) To begin to use behavioral modes avoided in the past because they were stressful or fearful.

Learning is more effective in step by step modeling in vivo with guided participation than in step by step modeling in vitro. In the first case the patient initially observes and then is guided to imitate a real model that interacts with a stressful object, e.g. a snake, in a sequence of conditions which become progressively more difficult or frightening for the patient. In the second case the patient watches the model on a video (Bandura, 1969; Paraskevopoulos, 1988). The pa- 
tient identifies with the therapist's value system. The tone of the therapist's voice informs the patient about what is considered normal or abnormal by the therapist. Therefore, it is extremely important that the psychotherapist's personality is characterized by "flexibility" and "freedom from extreme ideological and moral positions" (Marmor et al., 1981). It should always be remembered that psychotherapy primarily aims to satisfy the needs of the patient and not the needs of the therapist.

\section{6) Development of Self-control and Autonomy}

According to Strupp (1983) acquisition of self-control and autonomy are common targets of all types of psychotherapy. Strupp also claims that the terms "mastery", "ability to cope", "competence" and "independence" all refer to the following short description of psychoanalytic therapy given by Freud: "Where id was, there shall ego be". The patient should trust therapy and allow himself to depend on the therapist. That is, the more the patient allows themselves to rely on the therapist at the beginning of therapy, the more likely they are to become truly independent at the end of therapy (Strupp, 1983). The feeling of dependency towards their therapists which patients feel at the beginning or in the middle of therapy, particularly when positive results arise and the patients feel that there are changes in their life, often annoy both patients and their relatives. In these cases the analogy of learning a foreign language can be very useful. At the beginning of the lessons the trainee feels hopeless if they are asked to cope with the foreign language without the help of a teacher. Moreover, during this initial period the trainee feels completely dependent on the language teacher. However, later on, when enough learning takes place, the trainee becomes independent and they don't need a teacher any more. In fact, after a certain stage they may become better than the teacher.

Self-control acquired by the patient during therapy has all the features characterizing the techniques of conscious behavioral self-control as described by Paraskevopoulos (1988) and Fuchs \& Rehm (1977), that is: 1) Self-monitoring, 2) Stimulus control, 3) Competing responses, 4) Modifying actual behavior and 5) Self-reinforcement. All these arise in every psychotherapy even when the psychotherapist does not pay any special attention to them.

7) Rehearsal and confrontation

Finally, the rehearsal and the confrontation of the actual problem in vivo constitute common features of all psychotherapies (Marmor, 1975; Marmor et al., 1981; Strupp, 1983). Whatever happens in the psychotherapist's office is of no significance if it cannot help the patient cope with the actual problems in their life. Marmor (1975) proposes that "reality testing" in psychodynamic therapy trains the patient in new adoptive behaviors under the direct and indirect emotional support of their therapist. Therapeutic success relies on their confidence that they can cope with their fears. The above phenomena are clearly observable in the behavioral therapy of phobias. In the first description of systematic desensitization, Wolpe (1958) concluded that when a response which reduces anxiety arises simultaneously with a stressful condition, then the anxiety response is re- 
duced. This is an instance of the principle of "reciprocal inhibition" and usually is applied as the combination of deep muscular relaxation with step by step induction of the fearful conditions in the subject's imagination. The induction of the fearful conditions is accomplished in hierarchical order. Later, studies showed that many subjects reduce their fears during repeated baseline measurements before the conduct of the experiments. This was due to the exposure of these subjects to the fearful condition (Agras \& Berkowitz, 1988). Implosion therapy was thus introduced as a next step, in which the person is induced to imagine a fearful stimulus in its most threatening version and then try to experience the fear as much as possible (Polin, 1959). Flooding therapy is a variation of the previous therapy. In this the person is directed to experience rapidly, without any possibility to avoid it, the most stressful condition in its greatest tension (Polin, 1959). Because of the intense discomfort it produces in the patient, flooding is considered to be a "treatment of last choice", that is, it is used only when all other approaches have failed. This last technique is more effective than systematic desensitization and implosion therapy in the therapy of phobias (Agras \& Berkowitz, 1988). The same researchers conclude that systematic desensitization is effective as long it motivates patients to expose themselves in fearful conditions. However, studying the experimental findings, it seems that the beneficial outcome of systematic desensitization lasts longer than that of implosion and flooding. This improvement was found to last up to seven years after the end of therapy and is understood to be the result of the influence of desensitization on the cognitive procedures provoked by fear (Agras \& Berkowitz, 1988). In conclusion, the therapist should systematize the patient's fears in hierarchical order. Then, among other interventions, the therapist must advise the patient to confront their fears, firstly in imagination during the therapeutic sessions and then in vivo. In addition, the therapist should advise the patient to confront their fears step by step starting with the smaller ones. It would be better to make the first attempt when they are relatively calm.

\section{Glorious Past of Integrative Psychotherapy in Ancient Greece}

The widespread impression that psychotherapy is only about one century old and rests mainly on the cornerstone of Freudian theory [whose tripartite soul has strong similarities with Plato's (427-348 BC) soul divided to 1) the logistic

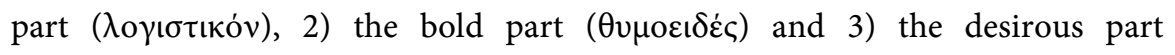

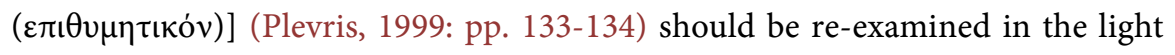
of the ancient Greek literature, even before the "Classical Age" of the 5th century BC. Evidence of psychotherapy is also found in the literature of other ancient civilizations (for example see Veith, 1975, for the traditional psychological foundations of the ancient civilizations of the far east; Venkoba Rao, 1975, for the Indus valley civilizations; Leon \& Rosselli, 1975 for the aboriginal psychological beliefs and practices in Latin America before the conquest; and Margetts, 1975, for the mental mechanisms of Indian and Eskimo Canadian aborigines, to men- 
tion just a few). Moreover, Empedocles (495-435 BC), long before Freud invented the Eros (Life) and Thanatos (Death) Instincts, suggested two forces go-

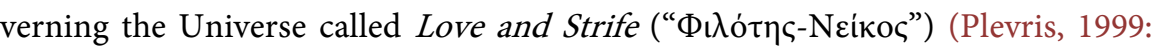
pp. 61-62). "Nعíкос" means to become "Victorious". Thus the defeated side does not necessary die. It can even benefit from its defeat.

Notwithstanding the contributions of other civilizations, it is clear from the "World History of Psychiatry" (for example see the compilation of papers covering almost all nations edited by Howells, 1975) that the contribution of the ancient Greeks is by far the most significant. Unfortunately the vast majority (about 95\%) of these ancient Greek writings has perished, especially after the burning down of the Library of Alexandria (see Canfora, 1986) and the many other catastrophic events which Greece had suffered in the past. It was the lost wealth of ancient Greek writings that has led to the statement that "modern psychology has reinvented the wheel many times" (Nestoros \& Vallianatou, 1990: p. 38).

The Thesaurus Linguae Graecae (TLG) is a research center at the University of California, Irvine. The TLG was founded in 1972 by Marianne McDonald (a graduate student at the time and now a professor of theater and classics at the University of California, San Diego) with the goal to create a comprehensive digital collection of all surviving texts written in Greek from antiquity to the present era. According to an undated in 2017 document on the TLG's web site, the total number of Greek words amounts to 110 million. There is a widespread impression, which remains to be proven by controlled studies, that employing the ancient Greek language increases the problem solving capacity of a person.

Focusing on the role of Greek alphabet, de Kerckhove \& Lumsden (1988) edited a textbook in 1988, which included chapters from scientists of many different fields (neuroscientists, linguists, psychologists, philologists etc., which concluded that its foundation had a significant role in the left lateralization of the brain which led to the development of rational, analytic and abstract thinking which have increased the brain's problem solving capacity. If we consider that Great Greeks from Alexander, who kept the Iliad under his sleeping pillow together with his dagger, according to Plutarch (1973), translated and annotated by Ian Scott-Kilvort in 1973 (pp. 259-260), to Aristotle Onassis, who always had o copy of Homer's Odyssey in all of his ships, airplanes, offices and houses (Forestier, 2006), we realize the importance of Greek literature. Moreover, Nobel Laureate Gerald M. Edelman (1992), dedicated his textbook “Bright Air, Brilliant Fire: On the matter of the Mind' published in 1992, to Empedocles (p. VII).

Ample evidence indicates that from the 6th century BC, during the healing

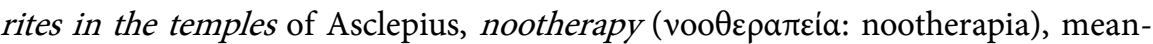
ing mind therapy - that is the therapy to change one's way of thinking-and repentance ( $\mu \varepsilon \tau$ ávola: metanoia) reached the status of sciences (Chessick, 1987). Today these therapies would be most likely classified as cognitive psychotherapies. Another form of widely employed therapy for psychological disturbances

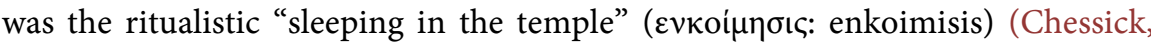


1987; Milns, 1986), which was probably a form of clinical hypnosis (Aravantinos, 1907; Kouretas, 1960) which is related to suggestion (like the placebo response). The recorded interactions between the client and the priest representing the God are very much in the line of modern integrative psychotherapy. Moreover, the ancient Greeks probably had some notion of nocebo, the evil twin of placebo, if we judge from various myths, including that of Oedipus (who was told by the oracle at Delphi that he was supposed to kill his father and marry his mother). Yet they definitely had a clear notion of placebo and employed it extensively, since the healing rites in the temples-among many other things-included baths (the clean body symbolically cleans the soul and prepares it for the therapeutic change) and ritualistic sleeping in the Temple (for the ancient Greeks this symbolically represented the death of the sick person, since Sleep was the brother of Thanatos, and his/her resurrection in to a new healthy person).

The brain circuitry involved in placebo and nocebo responses includes the rostral anterior cingulate, dorsolateral prefrontal and orbitofrontal cortices, insula, nucleus accumbens, amygdala, medial thalamus and periaqueductal gray ( $\mathrm{Zu}$ bieta \& Stohler, 2009; Schedlowski et al., 2015). Opioid and dopamine neurotransmission in these areas modulate various elements of the placebo effect, which appear to include "the representation of its subjective value, updates of expectations over time, changes in affective state and in pain ratings" (Zubieta \& Stohler, 2009).

The aforementioned circuitry also has the potential to modulate a number of functions beyond pain, as the brain regions involved have been implicated in the regulation of stress responses, neuroendocrine and autonomic functions, mood, reward and integrative cognitive processes, such as decision-making. The relevant literature points to neurobiological systems that when activated by "positive expectations", or "even pre-conditioning" are capable of inducing physiological change. They should therefore be considered as "resiliency mechanisms with the potential to aid in the recovery from challenges to the organism" (Zubieta \& Stohler, 2009).

The ancient Greek version of music and dance therapy employing the flute and the kettledrum can be found in the corybantic rituals celebrating the Phrygian deity of Cybele (see Dodds, 1951 and Milns, 1986, who recites Plato's Laws). These corybantic rituals are also believed to involve a form of catharsis (Milns, 1986). An appropriate musical mode was chosen for every particular illness. Flute music of the soft Phrygian mode was considered useful for people who were depressed and that of the graver Dorian mode was considered therapeutic to those suffering from abnormal elation of mood (Milns, 1986).

Various classical tragedies and comedies are full of interactions with psychotherapeutic significance. In one scene of the Bacchae, where, towards the end of the play, Agave is still holding her son's (Pentheus) bloody head, she is brought back to sanity by her old father in a masterful psychotherapeutic way. In this scene Agave is gradually made to acknowledge her monstrous act and to realize that she must learn to live with it (Milns, 1986). According to Devereux (1970), 
as cited by Milns (1986), "Euripides (480-406 BC) observed and described accurately and probably understood intuitively, not only psychological illness but also the psychotherapeutic process" and "(this) psychotherapeutic scene of the Bacchae is clinically flawless and persuasive; it will bear comparison with any modern summary of a psychotherapy session written by a professional clinician" (Devereux, 1970).

Moreover, in the plays of the famous comedian Aristophanes (446-386 BC) references to material of psychotherapeutic value are to be found. Particularly, in a passage from his play "The Wasps" he gives a long list of the different beneficial approaches to the treatment of psychological disturbances (Milns, 1986). Some of these, such as persuasion with soothing words and gentleness, can be easily recognized today as some of the common fundamental elements of all contemporary psychotherapeutic schools.

Furthermore, according to Milns (1986), ancient medical writers such as Hippocrates, Caelius Aurelianus, Celsus and Galen, emphasized the importance that we "talk to the patient and try to dispel his fantasies by reasoned argument. If, however, the patient becomes excited at being contradicted "we" should agree with (him) and humour his fantastic notions". Furthermore in their writings of Plato (Politeia, VI, 497D see edition by Adam, 1902; Philebus, 36C, see edition by Bury, 1973; Legg., I, 635B, Cambell, 1973) (as well as Jowett, 1964) the ancient Greeks believed that if we managed to realize what is that we are afraid of, then the fear disappears, as it makes no sense and has no real grounds of existence.

It is well known that Socrates was the first to assist his interlocutor find the solution to the problem by employing a particular conversation method, which became to be known as the "obstetrical method". Probably this approach is one of the best that psychotherapy has to offer, because the very process convinces the persons that they have within themselves the ability to find the solution to their problems (Nestoros \& Vallianatou, 1990: p. 37). Thus rightly Chessick (1987) in his book entitled "Great Ideas in Psychotherapy" considers Socrates to be the founder of psychotherapy.

While at the time of Socrates "psychotherapy" was a matter concerning a minority of "free" citizens, it later became very popular involving large segments of the population (probably larger than the percentage of people in psychotherapy in the Western world today) for seven centuries between the 3rd. Century BC and the 4th century AD. In this period two schools of philosophy which were clearly "psychotherapeutic" become predominant, the Epicurean school and the school of Stoicism, founded by the Cypriot Zenon of Kition (336-263 BC.) [Zeller \& Nestle, 1941/1994: see translation into Greek by Theodorides, 1941/1994 from 13th German edition; also Chessick, 1987]. The first promised absence of anxiety

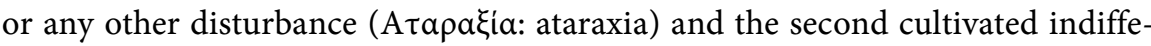
rence and detachment to external pleasant or unpleasant events (A $\pi \dot{\alpha} \theta \varepsilon\llcorner\alpha$ : apatheia). In other words both promised relief from anxiety provoked by the troubles of the times (Chessick, 1987).

Epicurus (341-270 BC) was a prolific writer, but since most of his work is lost, 
only some fragments of his teaching are known through his Roman student Lucretius (Chessick, 1987). With respect to the Stoics, the most important philosopher of the late classical period was Epictetus (AD 50-138). No writings of Epictetus himself have survived, although the "lecture notes" of his pupil Arrian, the famous "Enchiridion", were routinely employed by a Swiss director of a psychiatric hospital as reading material for his patients to combat their neuroses (see Copleston, 1962 and Chessick, 1987). There are also available to us today the "Meditations" of Emperor and philosopher Marcus Aurellius and a few other writings of the Stoics, which provide us with a very small and meagre sample of the glory that once was Greece. For example, it is claimed that another Cypriot, Chrysippus of Soloi, often referred to as the second founder of Stoicism, wrote more than seven hundred books (Chessick, 1987).

Moreover, the ancient Greeks were very much aware that mental health and wellness had a direct relationship with the ethics, attitudes and principles one employs in their everyday life. There are 147 Delphic Maxims inscribed in the Temple of Apollo. Three of them were located in the pediment of the Temple.

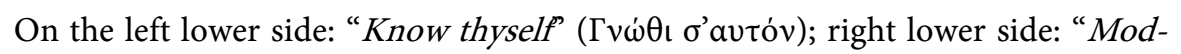

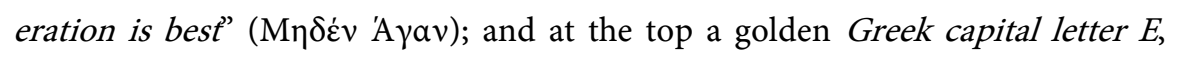
whose real meaning has been lost. Some of these 147 Maxims covering every possible aspect of life are the following: Follow God; Obey the law; Worship the Gods; Respect your parents; Be overcome by justice; Know what you have learned; Perceive what you have heard; Be/Know yourself; Intend to get married; Know your opportunity; Think as a mortal; Control yourself; Control anger; Cling to discipline; Respect yourself etc. They are all simple, direct and easily understood psychotherapeutic instructions which address all issues related to achieving harmony within one's self, their family and society. Moreover, they exhibit right away that the Greeks were very religious people, followed and worshiped the Gods and believed in supernatural powers. They believed that the symbol and the protector of the Human soul was the Sphinx, an animal with the body of a lion (corresponding to their biological nature and their similarity to other animals), a head definitely human (corresponding to all areas that humans differ from all other animals) and a pair of strong wings turned upwards (corresponding to the God-like elements of the human soul, which Plato and many other philosophers considered immortal). We add, that it logically follows that human beings are capable, at least under certain conditions, to achieve therapeutic goals impossible according to conventional scientific thinking. These obviously include the remedy through conscious and unconscious processes of a wide variety of physical and mental ailments. A surviving up to our days example of the "supernatural powers" of human beings is the ritualized "ecstatic" fire walking in certain areas o Northern Greece and Bulgaria called "Anastenaria" (Xygalatas, 2011).

Finally, three established facts must be emphasized:

1) In antiquity there were many different approaches towards the treatment of 
mental illness, extending from psychotherapy (by dialectic reasoning and magico-religious rituals) to somatic therapies, e.g. balanced diet, medications-such as black hellebore, massage, exercise, hot and cold baths and so on (Ducey \& Simon, 1975; Milns, 1986; Mora, 1975), which were applied at the same time to the same patient-which means that they were integrative-and.

2) In antiquity treatment was often provided at the patient's home and not only at mental institutions where treatment was of relative short duration (Ducey \& Simon, 1975; Milns, 1986; Mora, 1975). These two findings allow us to conclude that the ancient Greeks believed that mental illness was curable. That is the reason why they kept the patients in their homes and why they fought the illness using a variety of methods. Considering the concept of Hamilton (1973) that optimism is the main characteristic of "The Greek Way" of thinking, the "mark of the Greek spirit which distinguished it from all that has gone before", it follows that the rejection of the belief that mental illness is incurable becomes its greatest achievement in terms of the therapeutic process (see also Chessick, 1987: p. 68).

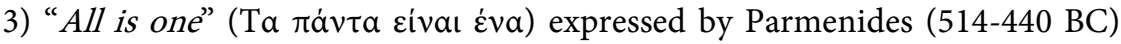
and adopted by Plato and Socrates (Plato's Parmenides, translation and analysis R. E. Allen, 1983) gave a strong philosophical foundation to the already existing for many centuries integrative approach.

\section{Melampus and Amphiaraos}

Melampus was according to Greek mythology the first mortal to be offered the charisma of divination (Pauly-Wissowa, 1931; Kakrides, 1986: pp. 178-181; Mpimpi-Papaspyropoulou, 1989) and became a most renowned diviner, psychotherapist and psychopharmacologist.

Melampus applied in mythical times a purely integrative and ingenious therapy to treat king Iphicles' impotence. Initially by discussing with the king he learned about a traumatic event that took place when the client was 4 years old. His father was castrating rams with a knife while his son was watching. At some point, his father, either hoaxing or "because the child had done something wrong" threatened Iphicles with the bloody Knife. Frightened young Iphicles run quickly away from his father in such a harry that probably contributed to him becoming a renowned runner with many wins in panhellenic games. His father, emotionally upset by the event, nailed the stained with blood knife on the trunk of a wild pear tree. The incident was forgotten and the knife was covered by the bark, branches and foliage of the tree. Iphicles, however became childless because of the well known psychodynamic concept of "castration anxiety". Melampus initially discussed with the king these past forgotten events bringing them to consciousness (insight oriented psychodynamic psychotherapy). Then he asked for the knife to be brought to him. He initially examined it and handled it by himself (participant modeling behavior therapy introduced in modern times by Albert Bandura) and consequently he gave the knife to his client to handle it, in order to desensitize him completely from the fear of it (flooding 
behavior therapy). He then removed the remnants of the blood from the knife and added them in to a strong wine. He told the king that by drinking a small glass of this "therapeutic wine" three times every day it was guaranteed that the queen will soon get pregnant \{thus using psychopharmacology (i.e. the biological approach), because alcohol is an anxiolytic, and suggestion to elicit the placebo response\}. Thus, king Iphicles had a son, Podarkes.

Melampus was the great-grandfather of Amphiaraos who inherited all of his divine properties (Kakrides, 1986: pp. 158-170). Amphiaraos became also a renowned diviner, was a priest of Apollo, the God of medicine and psychiatry, and was later deified himself (like Asclepius). Amphiaraos' Therapeutic Multicentre, called "Amphiaraeion" operated at Oropos for twelve centuries from the $6^{\text {th }}$ century $\mathrm{BC}$ to the $6^{\text {th }}$ century $\mathrm{AD}$. There were Amphiaraia specializing mostly in psychological problems all over the Greek world, working in parallel with the Asclepieia, specializing in Physical ailments, yet not exclusively. The Amphiaraion of Oropos was an ideal therapeutic Centre, located in a place of exceptional beauty and fine climate, a few kilometers from the sea on a hill full of pines, with running water around every building, with the temple of Amphiaraos, rooms for psychotherapy, diet consultation, cold and warm baths for men and women, rooms for enkoimisis, theatre, stadium and many other facilities which have not been excavated. Ancient authors describe a splendid altar decorated with Gods, demigods and human heroes. The story of how Amphiaraos was deified is very interesting. Amphiaraos was one of the two kings of Argos and was considered a great general in battle. Moreover, he was generally considered a very wise and ethical person who respected the Gods and prayed a lot, especially to Apollo (God of light, medicine and divination) and Zeus. Apollo was able, according to the ancient Greeks to inform people about the future by reading the mind of this father Zeus.

Amphiaraos was a moderate man. Although he had previously driven away Adrastos, the other competitor for the throne, he resolved the problem by marrying Erifyli, Adrastos' sister. Thus Argos had two kings, bound by oath that if they disagreed, Erifyli would decide, who was Amphiaraos' wife and Adrastos' sister. After Jocasta hanged herself and Oedipus blinded himself, their sons Eteocles and Polyneikes decided to rule on alternative years. When Polyneikes turn arrived, his brother refused to give him the throne. Bitter Polyneikes (his name is analyzed to mean quarrelsome) went to Argos, conducted Adrastos who gave him one of his daughters to marry, and started to raise an army against Thebes to reclaim his throne. Amphiaraos was against this expedition. His logic, his intuition and his ability to foresee the future suggested to him that only Adrastos will return alive. Yet Polyneikes had already pribed Erifyli with the neckless of Harmony, a very special piece of jewelry, given by the Gods to Harmony, daughter of Aphrodite and Mars, as a wedding gift when she married Cadmus, a mortal, who was one of the brothers of Europe and founder of Thebes. Amphiaraos, when Erifyli voted in favor of the expedition, knew what was going to happen, yet he was bound by oath. When he was ready to get on his 
chariot and leave Argos he told one of his sons: "If I do not return, kill your mother!"

The expedition against Thebes indeed failed and only one of the seven warlords, namely Adrastos, managed to remain alive. In the case of Amphiaraos, the following occurred. While he was chased by Periclymenus, son of Poseidon (Neptune), who was getting dangerously close and ready to kill him, Zeus threw a thunderbolt creating a chasm on earth, which allowed Amphiaraos, his chariot and his charioteer to escape alive under the earth. It is moving that up today you can find a road sign in the area of Oropos indicating that the place is still called "Arma" (the Greek word for Chariot). Amphiaraos was deified and gained a shrine, a Temple and a Therapeutic Centre at the point where he was raised from the darkness of earth to the light through the waters of a sacred fountain, which is located up to our days at the archeological site in the valley of the Amphiaraeion of Oropos.

\section{Hellenic Theoretical Integration of All Existing Psychotherapeutic Approaches}

The model presented here is named Hellenic, because according to Edith Hamilton (1930/1973), [in her book entitled "The Greek Way", based on a thorough study of Greek life and civilization, of Greek literature, philosophy and art], the chief characteristic of the Greek way of living is "optimism". Moreover, the first and by far the most important principle of this model is a philosophical one formulated by Heraclitus (trans. by Jones, 1931): "If you do not expect it, you will not find the unexpected, as it is hard to be sought out and difficult". \{which, in my opinion (as a Greek trained in Ancient Greek), is better translated as follows: "If you don't bear hopel you will never discover the unforeseen/ by rendering it inexplorable and beyond reach"\}.

If the ancient Greeks synthesized all possible therapeutic approaches, why not attempt this exercise today?

1) Behavioral therapeutic approaches: Since they all have to do with learning, by their very nature they cannot be in conflict with any other therapeutic approach, that is the psychodynamic, humanistic/existential, systemic and biological approaches. This is because learning is involved in all normal and abnormal psychological states, regardless of the theoretical approach employed to interpret the psychological phenomena. Moreover, the present model considers that Classical Conditioning (Ivan Petrovich Pavlov, John B. Watson and others.), Operant Conditioning and Behavioral Analysis (B. F. Skinner and others), Social Learning (Albert Bandura and others), Purposive Behaviorism (Edward Tolman and others), Rational Emotive Therapy (Albert Ellis and others), Cognitive Behavioral Therapy (CPT) (Aaron T Beck and others) and Psychological Behaviorism (Arthur W. Staats and others) to be closely interrelated and complementary to each other.

2) Biological therapeutic approaches (psychopharmaca, herbs, diet, physical 
exercises, massage therapy, warm and cold baths, thalassotherapy, exposure to the sun etc.) by their very nature they cannot be in conflict with any other therapeutic approach, that is the psychodynamic, behavioral, humanistic/existential and systemic approaches. That is because we consider that all psychological states and functions, both normal and psychopathological, are related to specific brain and other central nervous system activity as well as to endocrine and other bodily activities. That is we consider the body and the mind as one entity and the brain to be the temple of the psyche. In that sense psychological functions are equivalent to brain functions.

3) Systemic therapeutic approaches stemming from "systems theory" and "cybernetics" (the two terms are widely used as synonyms) was introduced by biologist L. von Bertalanffy (1929) as a modeling device that accommodates the interrelationship and overlap between different disciplines (for example philosophy and the different sciences, such as neurochemistry and mathematics). By their very nature Systemic therapeutic approaches cannot be in conflict with any other therapeutic approaches, that is the psychodynamic, behavioral, humanistic/existential and biological approaches. If systems theory can facilitate the understanding and communication between entirely different sciences, it can be of great use facilitating the understanding of human behavior and its interaction with psychotherapists, with computers (Wiener, 1948), and with the characteristics of the environment (i.e. Therapeutic architecture).

4) The integration of psychodynamic with humanistic/existential perspectives appears at first consideration impossible, since the former emphasizes unconscious processes and the latter stresses the power of conscious free will as a reaction to the pessimistic views of both early psychodynamic theory (supremacy of the id over the ego according to Freud (1927) leading to intrapsychic determinism, and early behavioral (Skinner, 1971; Watson, 1924) approaches suggesting environmental determinism. This conflict is solved by viewing human beings as not necessarily exercising conscious free will unless they become aware of their potential to do so. Furthermore, this awareness of the freedom of choice over one's behavior, thoughts and feelings is a common goal cultivated by all modern psychotherapists.

Therefore the second principle of "Hellenic Integrative Psychotherapy: A total holistic approach" is that the integration of all possible perspectives employed to ameliorate and/or improve human behavior (including thoughts, feelings, relating to self and others, reduction of stress, augmented cognition via brainwave entrainment etc.) is not only possible, but all possible interventions a) complement each other and b) amplify the beneficial effect of the other intervention.

The third principle of this model is that most people suffer because of the way their parents influenced them at an early developmental age (usually before 4 years of age) through the mechanism of social learning and in many other ways. At the time the child was unable to defend his/her selves or even chose whether the behavior copied was to his/her benefit. Nevertheless, it is absolutely pointless for the client to start a war with their parents, since a) the parents' themselves 
are the victims of their own parents, who are the victims of their great grandparents and so forth; and b) parents very rarely damage their children consciously. In other words they don't do it on purpose. The child is an innocent bystander who happens to receive the consequences of their parents' psychological dysfunction. Moreover, once a person is old enough in late adolescence-early adulthood to understand psychological processes and to be responsible for their own behavior, in psychotherapy they learn to take responsibility for their own thoughts, decisions, feelings and behavior and not blame their parents or anybody else for what they feel inside.

The fourth principle of this model addresses the issue that the symptoms of psychological disorders (panic attacks, depression, schizophrenic symptoms etc.) by themselves are never as bad as the suffering person's or society's reaction to them, because of the existing ignorance and prejudice against mental illness among the general public and many mental health professionals. In our point of view, we consider it unethical to work as a mental health professional if you do not believe that mental illness is curable or at least amenable to improvement. If a client asks: "Is my condition treatable?" we would ask him back "Do you really, at least at the conscious level, want to get well?". The answer is usually "Yes" or "Of course!" Then the client is asked: "Are you willing to invest energy, time and money for a period of two to four years, in order to deal with your psychological problem?" If the answer is yes, we comment that "we do not know of any person who had committed themselves to the above conditions of therapy, regardless of the severity of their problems and/or the severity of their diagnosis according to DSM-5, who were not able to completely change their lives in a better direction!"

The fifth principle of this model addresses the issue that most if not all types of psychopathological symptoms are driven by stress. This principle of course extends to psychosomatic disorders. The author has extensive clinical and research experience with clients meeting diagnostic criteria for Paranoid Schizophrenia and Schizoaffective Disorder. In my clinical experience extending to many thousands of hours of interacting with this kind of clients, no body hallucinated in my office if they started to feel calm after the initial sessions. Delusions were more resistant to treatment, but they definitely diminished after months of intensive psychotherapy, when the client felt less stressed. I have done innumerable measurements repeatedly (up to five times a week for up to more than two years) with psychometric tests with more than one hundred of these clients to reach the conclusion that their symptoms showed tremendous deviations which were definitely stress related. I have also carried out controlled experiments which were presented in scientific meetings and were published in refereed scientific journals. In one study we found that just one good integrative psychotherapy session lasting one hour which was judged as good by both client and therapist because of the reduction of stress led to a significant decrease of schizophrenic symptoms. On the contrary, a bad session which ended up with a stressed client significantly increased schizophrenic symptoms (Zgantzouri, Vallianatou, \& Nestoros, 2006). This particular study proves that Schizophrenic 
symptoms can be ameliorated by stress reduction. It is of great interest that the same beneficial results on Schizophrenic symptoms can be achieved through high doses of diazepam (an anxiolytic, i.e. a stress reducing, benzodiazepine drug) (Nestoros et al. 1982, 1983; Lingjaerde, 1985).

The sixth principle of this model addresses the issue that most people are not aware of their emotions, do not understand their psychological reactions and in short exhibit low emotional intelligence (Goleman, 1995). For this reason the majority of psychotherapy sessions are devoted in bringing to light by employing the obstetrical method of Socrates the forgotten knowledge that our clients have about these most crucial for their survival in our society topics. We do not act as traditional teachers, neither we provide advice as counsellors do. We restrict ourselves in asking the right questions with the firm belief that every person can identify their psychological problems and furthermore discover the best possible solutions. Provided of course that there is no pressure and no deadline settings. A common advise to trainees in our Hellenic Integrative Psychotherapy program is the following: "If you feel your patient is not moving on, relax. Just do not write him off and do not give up on him. Let him do it his way. Wait for him. The word "Therapy" in ancient Greek means to be present by the patient's bed. And great Hippocrates said "to help or at least cause no harm"! ...Wait for him, and one day you will be surprised!"

The seventh principle of this model addresses the issue of how one can be a good psychotherapy client. I have devised the following advice from reading a book about colors. "If you want to be a good psychotherapy client, you have to start accepting and loving yourself right now! Immediately right now with all your flaws, defects and disadvantages. Do not tell yourself that you will love him/her when you get rid of your shortcomings... If you follow my advice, your real self, who is hiding with shame will start revealing himself to you... And the more your true self is revealed to you, you will find a million reasons to accept and love yourself in just the way you are right now!"

The eighth principle of this model addresses the issue that mistakes, misfortunes and unpleasant experiences are an integral part of real life. A person who expects to live up to 110 years old and has the attitude that even in the last day of his life he will have to address some serious problem, is likely to live a happier life than somebody who believes that, for whatever reason, all his problems will be gone after a certain day. There is no day and time in a person's life that one can rest assured that everything will go following their wishes. Even in the best organized holidays! The ancient and modern Greeks believe that there is nobody who has made no mistakes. Even god Dionysius went mad. The great hero of the Trojan war Ajax, committed suicide after a psychotic episode. Great Hercules also became insane and killed his children and his beloved wife Megara. On lighter kinds of mistakes the Greeks believe that we can learn from our mistakes.

The more mistakes we make, the more wealthy we become, provided that we learn from them. Moreover, many modern Greeks believe that life chooses to give great misfortunes to those who can withstand them. This is a way for 
somebody to feel special because fortune has chosen him for such an experience. This Greek attitude reminds one of the lyrics by Billy Ocean (1986) in his album "Love Zone": "When the Going Gets Tough, the Tough Get Going". Finally, the way a modern Greek person handles tragedies (like the death of a loved one) is very important. "My hardships make me happy, my bitter experiences I celebrate boisterously" (lyrics from a traditional rebetico song, probably from Smyrna, Asia Minor, around 2015). A Greek is expected to face a tragedy with compassion, because he puts great value on life, but at the same time with braveness, since he defies death.

The ninth principle of this model addresses the issue of evidence-based data that support is effectiveness, in the spirit of the authors in the volume edited by Norcross (2011). It has been taught for 28 academic years at the Department of Psychology through 20 videotaped sessions of the same patient, who not only gave her permission for her sessions to be used as teaching material, but often spoke face to face with undergraduate and postgraduate in clinical psychology students in order to provide explanations regarding her integrative psychotherapy sessions. The text of her sessions was deciphered painstakingly by the postgraduate students in clinical psychology and are available for further study and research, as part II, pp. 157-665 (out of the total 752 pages) in the textbook by the undersigned (Nestoros, 2012a) entitled "Integrative Psychotherapy", $2^{\text {nd }}$ improved edition. Many other cases with psychosis are presented in detail, again with the text of the sessions painstakingly deciphered by postgraduate students in clinical psychology in another textbook (Nestoros, 2012b) entitled "In the world of Psychosis" (pages 832). Many papers were presented in International Scientific Meetings, a major Textbook was co-edited with Prof. P.J. Hawkins (Psychotherapy: New perspectives on Theory, Practice and Research, 1997, with 20 chapters, 703 pages long, which included chapters Nestoros, 1997a, 1997b and Hawkins \& Nestoros, 1997), chapters in Textbooks (in E. O'Leary \& M. Murphy (Eds.), New Approaches to Integrative Psychotherapy contribution with 3 chapters. Nestoros, 2006; Nestoros et al., 2006; Kalaitzaki \& Nestoros, 2006) as well as Nestoros 2016 (in J. Birtchnell, M. Newberry \& A. Kalaitzaki (Eds), Relating Theory. Clinical, Forensic and other Applications) - among many other chapters in Textbooks. For example, Nestoros et al., 1998. Finally, many papers were submitted to refereed scientific journals and were accepted for publication (Zgantzouri, Vallianatou, \& Nestoros, 2006; Kalaitzaki, Birtchnell, \& Nestoros 2009, 2010; Benioudakis et al., 2016; Zgantzouri \& Nestoros, 2017; Nestoros et al., 2017). All focused on Integrative Psychotherapy mostly with clients meeting diagnostic criteria for paranoid schizophrenia and/or schizoaffective psychosis. Thus as the publications show, we have obtained evidence-based results that the Hellenic integrative psychotherapy model exerted significant beneficial effects both on the clients themselves as well as and on their interrelations with family members. It should be stressed that all clients in the above studies met diagnostic criteria for paranoid schizophrenia and/or schizoaffective psychosis. Lastly, since 1993, I was a member of the Board of Directors of the European Institute of 
Psychotherapy and in that capacity I taught in Intensive Erasmus programs Integrative Psychotherapy of Schizophrenia in the following countries: Finland, England, Ireland, Portugal, Spain, France, Italy, Cyprus and Greece.

The tenth principle of this model addresses the issue its integration with Neurofeedback and Event Related Potentials (ERPS). Neurofeedback training systems also has been widely investigated, tested and used as an effective method for cognitive, creative and physical human enhancement in performance oriented contexts (Gruzelier et al, 2010; Gruzelier et al, 2014; Thompson et al, 2008; Schmorrow et al., 2004). Our approach, while building upon the already rich research on Systems Neuroscience, Brain Augmentation, Augmented Cognition and Neuro-feedback training, bridges them for the first time into a novel integrated technology and new interdisciplinary research field that effectively combines neuroscience, computer science, engineering, psychology and education, in order to produce scientific theories, methodologies and technological tools aiming to enhance human skills, learning potential and intelligent problem solving abilities (Argento et al, 2017). Furthermore, the new imaging method $s$ LORETA is fully described (Pascual-Marqui, 2002). The sLORETA method yields images of standardized current density with zero localization error. The accuracy of these results cannot be improved upon. No other instantaneous, distributed, discrete, imaging method for EEG/MEG has been published that achieved perfect localization. All other previously published methods at best produced systematic non-zero localization errors. Experimental validation for $s$ LORETA was demonstrated with visual ERPs to stimulation with pictures of human faces (Pascual-Marqui et al., 2002). In recent years an improved system named “exact LORETA" (eLORETA) was introduced (Pascual-Marqui, 2007, Pascual-Marqui, 2009; Pascual-Marqui \& Biscay-Lirio, 2011). The above methodology will allow us to understand which brain structures are involved in various specific psychopathological states and in specific psychotherapeutic processes. Moreover, they will elucidate the mode of action of Psychoactive substances, Hippocratic diet, Physical exercise, Therapeutic physical environment, Therapeutic Architecture, Thalassotherapy, Therapeutic Greek philosophy and culture and all other therapies mentioned in this article.

The eleventh principle of this model addresses the issue that "Humans appreciate a wide range of entities aesthetically: painting, sculpture, music, opera, theatre, literature, design and buildings but also faces, flowers, landscapes, food, machinery, habitats and various objects of everyday life" (Doherty et al., 2003; Jacobsen, 2010). Since we adhere to Theodor Dostoevsky's belief that “Beauty will save the world" we attribute great attention to the therapeutic effects of beauty and harmony found in Greek nature. Thus we believe that living in Greece as close as possible to Greek nature and interacting with anything purely Greek will by itself be enough to reduce stress related psychological and psychosomatic problems and increase wellness and quality of life.

The twelfth principle of this model addresses the issue of developing new treatments through research assisted by computers, which apart from the tradi- 
tional psychometric tests will contribute to the evaluation of the results from traditional therapies and also offer a variety of new therapies, such as Neurofeedback, Brain Augmentation, Augmented Cognition, through novel integrative technology (Argento et al., 2017). The assistance offered by computers is enormous. For example you can become a Master of Zen meditation by practicing it for years or you can have the characteristic alpha rhythm in your EEG immediately, for as long as you want, by having a Neurofeedback session. Some scientists believe that humans will soon be controlled slaves of Computers who will have their own consciousness, self-awareness and free will. I am certain that in our Hellenic model, which has within its principles that psychotherapy "increases the client's freedom" trainees will never be enslaved by computers. We should keep in mind that in their innumerous revolutions the Greeks always chanted "Freedom or Death"! And that the national anthem of Greece is the "Hymn for the Liberty".

\section{Conclusion}

We have demonstrated how ancient Greek philosophy and culture created an integrative approach to medicine, mental health and wellness and obviously we consider our "Hellenic Integrative Psychotherapy: A total holistic approach" to be very much related to that specific way of thinking. We believe that all great cultures (like the Chinese etc.) can very much improve the Hellenic Approach and we look very much forward to such an exchange of ideas and dialogue.

The first version of the Hellenic Integrative Psychotherapy model was presented at a Congress named "Amphiaraia, 1990" under the Greek name

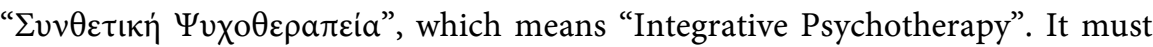
be emphasized that although this model was constructed using the idealistic approach, it has been vigorously tested using the evidence-based approach and has been proven to exert a great therapeutic effect on difficult psychiatric patients such as those meeting diagnostic criteria for paranoid schizophrenia and schizoaffective psychosis.

So far in SYNCHRONAL AMPHIARAIA we were able to provide: a) psychotherapeutic sessions to individuals, couples, families and groups; b) psychopharmacological therapy on an individual basis; c) Neurofeedback, also on an individual basis and d) a combination of two or all three of the above therapies. We are in the process of building or renovating facilities in order to provide the other aforementioned Hellenic therapeutic approaches. Those are: e) Therapeutic architecture (Jacobsen, 2010); f) Therapeutic natural environment (Jacobsen, 2010); g) Hippocratic diet (Hawley \& Gibala, 2012; Yapizakis, 2009); h) Physical exercise (Haslam \& Pract, 2016; Hawley \& Gibala, 2012); i) Therapeutic thermal and cold baths (Moss, 2010; van Tubergen \& van Linden, 2002; Zijlstra et al., 2005); j) Thalassotherapy (Charlier \& Chaineux, 2009); k) Exposure to sunlight (Benedetti et al., 2001; Walch et al., 2005); l) Music therapy (McClellan, 1991); m) Theater therapy (Boal, 1995); n) Art therapy (Gilroy, 2006); q) Courses and discussions in small and large groups about Greek mythology, language, history, 
philosophy, literature, ethics, values, reasoning, mentality and way of life (Hamilton, 1973; Etienne \& Etienne, 1990/2000; Panaretou, 2003); r) Expansion of Neurophysiology Laboratories (Pascual-Marqui \& Biscay-Lirio, 2011; Argento et al., 2017).

Thus, our model is in the same line of thought with Arnold Lazarus' (1981) multimodal therapy, yet it includes many more factors influencing behavior, affect, sensations, imagery, cognition, interpersonal relationships and biological functions. In addition to the former model, our model includes computer-assisted neurophysiological assessments and treatments and aspires to explore brain function(s) underlining all mental states, including psychopathology, psychotherapy, personality, and human nature in all of its possible expressions, including wellness.

We are pleased to observe that other Greek researchers utilize ancient Greek philosophy in the reduction of stress. For example a model of "Pythagorian self-awareness" has been employed with promising results (Darviri et al., 2016a, 2016b).

\section{References}

Adam, J. (1902). Plato's “The Republic” (Politeia). Cambridge: University Press.

Agras, W. S., \& Berkowitz, R. (1988). Behavior Therapy. In J. A. Talbott, R. E. Hales, \& S. C. Yudofsky (Eds.), Textbook of Psychiatry (pp. 891-905). Washington DC: American Psychiatric Press.

Alexander, F. (1963). The Dynamics of Psychotherapy in Light of Learning Theory. American Journal of Psychiatry, 120, 440-448. https://doi.org/10.1176/ajp.120.5.440

Alexander, F., \& French, T. (1946). Psychoanalytic Therapy. New York, NY: Ronald.

Allen, R. E. (1983). Plato's Parmenides: Translation and Analysis.

Aravantinos, A. P. (1907). Asklipios kai Asklipieia. Miami, FL: Leon Publications.

Argento, E., Papagiannakis, G., Baka, E., Maniadakis, M., Trahanias, P., Sfakianakis, M., \& Nestoros, J. (2017). Augmented Cognition via Brainwave Entrainment in Virtual Reality: An Open, Integrated Brain Augmentation in a Neuroscience System Approach. Augmented Human Research, 2, 1-14. https://doi.org/10.1007/s41133-017-0005-3

Arkowitz, H. (1992). Integrative Theories of Therapy. In D. Freedheim (Ed.), The History of Psychotherapy: A Century of Change (pp. 261-303). Washington DC: American Psychological Association. https://doi.org/10.1037/10110-007

Bandura, A. (1962). Social Learning through Imitation. In M. R. Jones (Ed.), Nebraska Symposium on Motivation (pp. 211-269). Lincoln, NE: University of Nebraska Press.

Bandura, A. (1969). Principles of Behavior Modification. New York, NY: Holt.

Bandura, A. (1973). Aggression: A Social Learning Analysis. Englewood Cliffs, NJ: Prentice-Hall.

Bandura, A. (1977). Social Learning Theory. Englewood Cliffs, NJ: Prentice-Hall.

Beitman, B. D., Goldfried, M. R., \& Norcross, J. C. (1989). The Movement toward Integrating the Psychotherapies: An Overview. American Journal of Psychiatry, 146, 138-147. https://doi.org/10.1176/ajp.146.2.138

Benedetti, F., Colombo, C., Barbini, B., Campori, E., \& Smeraldi, E. (2001). Morning Sunlight Reduces Length of Hospitalization in Bipolar Depression. Journal of Affective 
Disorders, 62, 221-223. https://doi.org/10.1016/S0165-0327(00)00149-X

Benioudakis, S. E.,' Kountzaki, S., Batzou, K., Markogiannaki, K., Seliniotaki, T., Darakis, E., Saridaki, M., Vergoti, A., \& Nestoros, N. J. (2016). Can Neurofeedback Decrease Anxiety and Fear in Cancer Patients? A Case Study. Advances in Psychiatry and Neurology, 25, 59-65. https://doi.org/10.1016/j.pin.2015.12.001

Boal, A. (1995). The Rainbow of Desire: The Boal Method of Theatre and Therapy (Translated by Andrian Jackson). New York, NY: Rontledge.

Bury, R. G. (1973). The Philebus of Plato (Edited with Introduction, Notes and Appendices). New York, NY: Arno Press.

Cambell, L. (1973). Plato's Sophistis and Politicus. New York, NY: Arno Press.

Canfora, L. (1986). La biblioteca scomparsa. Palermo: Sellerio editore.

Castelnuovo-Tedesco, P. (1979). The Fear of Change and Its Consequences in Analysis and Psychotherapy. Psychoanalytic Inquiry, 9, 101-118.

https://doi.org/10.1080/07351698909533757

Castonguay, L. G., \& Goldfried, M. R. (1994). Psychotherapy Integration: An Idea Whose Time Has Come. Applied and Preventive Psychology, 3, 159-172. https://doi.org/10.1016/S0962-1849(05)80068-X

Charlier, R. H., \& Chaineux, M. C. P. (2009). The Healing Sea: A Sustainable Coastal Ocean Resource: Thalassotherapy. Journal of Coastal Research, 25, 838-856. https://doi.org/10.2112/08A-0008.1

Chessick, R. D. (1987). Great Ideas in Psychotherapy. Northvale, NJ: Jason Aronson.

Copleston, F. (1962). A History of Philosophy (Vol. 1, Part 1 \& 2). Garden City: Doubleday.

Darviri, C., Zavitsanou, C., Delikou, A., Giotaki, A., Artemiadis, A., Terentiou, A., \& Chrousos, P. G. (2016a). A Novel Non-Pharmaceutical Treatment for Patients with Mild Cognitive Impairment. Psychology, 7, 678-686.

https://doi.org/10.4236/psych.2016.75070

Darviri, C., Zavitsanou, C., Delikou, A., Giotaki, A., Artemiadis, A., Anagnostouli, M., Varvogli, L., Vasdekis, S., \& Chrousos, G. P. (2016b). Pythagorean Self-Awareness Serves Successfully as a New Cognitive Behavioral-Based Technique in Multiple Sclerosis Physical and Psychosocial Well-Being and Quality of Life. Psychology, 7, 572-583. https://doi.org/10.4236/psych.2016.74059

De Kerckhove, D., \& Lumsden, C. J. (1988). The Alphabet and the Brain: The Lateralization of Writing. Berlin, Heidelberg: Springer-Verlag. https://doi.org/10.1007/978-3-662-01093-8

Devereux, G. (1970). The Psychotherapy Scene in Euripide's Bacchae. Journal of Hellenic Studies, 90, 35-48. https://doi.org/10.2307/629752

Dodds, E. R. (1951). The Greeks and the Irrational. Berkeley, CA: University of California Press.

Doherty, O. J., Winston, J., Critchley, H., Perrett, D., Burt, D. M., \& Dolan, R. J. (2003). Beauty in a Smile: The Role of Medial Orbitofrontal Cortex in Facial Attractiveness. Neuropsychologia, 41, 147-155. https://doi.org/10.1016/S0028-3932(02)00145-8

Ducey, C., \& Simon, B. (1975). Ancient Greece and Rome. In J. G. Howells (Ed.), World History of Psychiatry (pp. 1-38). New York, NY: Brunner/Mazel.

Edelman, G. M. (1992). Bright Air, Brilliant Fire: On the Matter of the Mind. New York, NY: Basic Books.

Eisen, P. (1979). Negative Capability as a Factor Problem-Solving within the Psychothe- 
rapeutic Process. Australian and New Zealand Journal of Psychiatry, 13, 27-34. https://doi.org/10.3109/00048677909159106

Etienne, R., \& Etienne, F. (1990/2000). The Search for Ancient Greece: New Horizones. London: Thames \& Hudson.

Feidler, F. E. (1950). A Comparison of Therapeutic Relationships in Psychoanalytic, Nondirective and Adlerian Therapy. Journal of Consulting Psychology, 14, 436-445. https://doi.org/10.1037/h0054624

Forestier, F. (2006). Aristote Onassis. Editions Michel Lafon.

Frank, J. (1973). Persuasion and Healing. Baltimore, MD: John Hopkins University Press.

French, T. M. (1933). Interrelations between Psychoanalysis and the Experimental Work of Pavlov. American Journal of Psychiatry, 89, 1165-1203. https://doi.org/10.1176/ajp.89.6.1165

Freud, S. (1927). The Ego and the ID. London: Institute for Psychoanalysis and Hogarth Press.

Fuchs, C. Z., \& Rehm, L. P. (1977). A Self-Control Behavior Therapy Program for Depression. Journal of Consulting and Clinical Psychology, 45, 206-215. https://doi.org/10.1037/0022-006X.45.2.206

Gilroy, A. (2006). Art Therapy, Research and Evidence-Based Practice. London: SAGE.

Goldfried, M. R., \& Newman, C. (1986). Psychotherapy Integration: A Historical Perspective. In J. C. Norcross (Ed.), Handbook of Eclectic Psychotherapy. New York, NY: Brunner/Mazel.

Goleman, D. (1995). Emotional Intelligence: Why It Can Matter More than IQ. New York: Bantam Books.

Grunebaum, H. (1986). Harmful Psychotherapy Experience. American Journal of Psychotherapy, 40, 165-176. https://doi.org/10.1176/appi.psychotherapy.1986.40.2.165

Gruzelier, J. H., Foks, M., Steffert, T., Chen, M. J. L., \& Ros, T. (2014). Beneficial Outcome from EEG-Neurofeedback on Creative Music Performance, Attention and WellBeing in School Children. Biological Psychology, 95, 86-95. https://doi.org/10.1016/j.biopsycho.2013.04.005

Gruzelier, J., Inoue, A., Smart, R., Steed, A., \& Steffert, T. (2010). Acting Performance and Flow State Enhanced with Sensory-Motor Rhythm Neurofeedback Comparing Ecologically Valid Immersive VR and Training Screen Scenarios. Neuroscience Letters, 480, 112-116. https://doi.org/10.1016/j.neulet.2010.06.019

Hamilton, E. (1973). The Greek Way. New York, NY: Avon Books.

Haslam, D., \& Pract, J. C. (2016). Weight Management in Obesity-Past and Present. Review Article. International Journal of Clinical Practice, 70, 206-217. https://doi.org/10.1111/ijcp.12771

Hawkins, P. J., \& Nestoros, J. N. (1997) Beyond the Dogmas of Conventional Psychotherapy: The Integration Movement. In P. J. Hawkins, \& J. N. Nestoros (Eds.), Psychotherapy: New Perspectives on Theory, Practice and Research (pp. 23-95). Athens: Ellinika Grammata Publishers.

Hawley, J. A., \& Gibala, M. J. (2012). What's New since Hippocrates? Preventing Type 2 Diabetes by Physical Exercise and Diet. Diabetologia, 55, 535-539.

https://doi.org/10.1007/s00125-012-2460-1

Heine, R. W. (1953). A Comparison of Patients' Reports on Psychotherapeutic Experience with Psychoanalytic, Nondirective and Adlerian Therapists. American Journal of Psychotherapy, 7, 16-23. https://doi.org/10.1176/appi.psychotherapy.1953.7.1.16 
Heraclitus (1931). On the Universe (Trans. W. H. S. Jones). In G. P. Good (Ed.), The Loeb Classical Library, LCL 150 (pp. 449-509). Cambridge, MA: Harvard University Press.

Horvath, A. O., Del Re, A. C., Flückiger, C., \& Symonds, D. (2011). Alliance in Individual Psychotherapy. Psychotherapy, 48, 9-16. https://doi.org/10.1037/a0022186

Howells, J. G. (1975). World History of Psychiatry. New York, NY: Brunner/Mazel.

Jacobsen, T. (2010). Beauty and the Brain: Culture, History and Individual Differences in Aesthetic Appreciation. Journal of Anatomy, 216, 184-191. https://doi.org/10.1111/j.1469-7580.2009.01164.x

Jowett, M. A. (1964). The Dialogues of Plato (Translated into English with Analyses and Introductions). Oxford: The Clarendon Press.

Kakrides, I. T. (1986). Hellenic Mythology. Vol. 3, The Heroes and Local Traditions. Athens: Ekdotike Athenon.

Kalaitzaki, A. E., \& Nestoros, J. N. (2006). Integrating Individual and Family Therapy in Improving Negative Interrelating within Families of Persons with Schizophrenic Symptoms. In E. O'Leary, \& M. Murphy (Eds.), New Approaches to Integrative Psychotherapy (pp. 141-154, Chapter 12). London: Brunner-Roudledge.

Kalaitzaki, A. E., Birtchnell, J., \& Nestoros, J. N. (2009). Interrelating within the Families of Young Psychotherapy Outpatients. Clinical Psychology \& Psychotherapy, 16, 199-215. https://doi.org/10.1002/cpp.613

Kalaitzaki, A., Birtchnell, J., \& Nestoros, J. N. (2010). Does Family Interrelating Change over the Course of Individual Treatment? Clinical Psychology \& Psychotherapy, 17, 463-481. https://doi.org/10.1002/cpp.687

Kouretas, D. (1960). Neotropoi ekfanseis ton psychotherapevtikon methodon aitines efirmozonto eis ta iera temeni tis archaias Ellados. Parnassos, Vol. B, No 4.

Larson, D. (1980). Therapeutic Schools, Styles, and Schooling: A National Survey. Journal of Humanistic Psychology, 20, 3-20. https://doi.org/10.1177/002216788002000302

Lazarus, A. (1981). The Practice of Multimodal Therapy. New York, NY: McGraw-Hill.

Leon, C. A., \& Rosselli, H. (1975). Latin America. In J. G. Howells (Ed.), World History of Psychiatry (pp. 476-506). New York, NY: Brunner/Mazel.

Lingjaerde, O. (1985). Antipsychotic Effect of Benzodiazepines. In G. D. Burrows, T. R. Norman, \& G. D. Davies (Eds.), Drugs in Psychiatry (Vol. 3, Antipsychotics, Chapter 13, pp. 163-172). Amsterdam: Elsevier.

Margetts, E. L. (1975). Canada. In J. G. Howells (Ed.), World History of Psychiatry (pp. 400-431). New York, NY: Brunner/Mazel.

Marmor, J. (1962). Psychoanalytic Therapy as an Educational Process. In J. Masserman (Ed.), Science and Psychoanalysis (Vol. 5, pp. 286-299). New York, NY: Grune and Stratton.

Marmor, J. (1964). Psychoanalytic Therapy and Theories of Learning. In J. Masserman (Ed.), Science and Psychoanalysis (Vol. 7, pp. 265-279). New York, NY: Grune and Stratton.

Marmor, J. (1966). The Nature of the Psychotherapeutic Process. In G. Usdin (Ed.), Psychoneurosis and Schizophrenia (pp. 66-75). Philadelephia: J. B. Lippincott Co.

Marmor, J. (1975). The Nature of the Psychotherapeutic Process Revisited. Canadian Psychiatric Association Journal, 20, 557-565. https://doi.org/10.1177/070674377502000801

Marmor, J., Castelnuovo-Tedesco, P., \& Lewis, J. M. (1981). The Psychotherapeutic 
Process. Psychiatric Update, 1, 1-9.

McClellan, R. (1991). The Healing Process of Music. Rockport, MA: Element, Inc.

Milns, R. D. (1986). Attitudes towards Mental Illness in Antiquity. Australian and New Zealand Journal of Psychiatry, 20, 454-462. https://doi.org/10.3109/00048678609158898

Mora, G. (1975). Italy. In J. G. Howells (Ed.), World History of Psychiatry (pp. 39-89). New York, NY: Brunner/Mazel.

Moss, G. A. (2010). Water and Health: A Forgotten Connection? Perspectives in Public Health, 130, 227-232. https://doi.org/10.1177/1757913910379192

Mpimpi-Papaspiropoulou, A. (1989). Conference Proceedings of Argolid Studies (1986), Athens.

Nestoros, J. N. (1997a). A Model of Training in the Methodology of Individual Psychotherapy Research: The Case of Schizophrenia as a Paradigm. In P. J. Hawkins, \& J. N. Nestoros (Eds.), Psychotherapy: New Perspectives on Theory, Practice and Research (pp. 633-681). Athens: Ellinika Grammata Publishers.

Nestoros, J. N. (1997b). Integrative Psychotherapy of Individuals with Schizophrenic Symptoms. In P. J. Hawkins, \& J. N. Nestoros (Eds.), Psychotherapy: New Perspectives on Theory, Practice and Research (pp. 321-363). Athens: Ellinika Grammata Publishers.

Nestoros, J. N. (2006). Recent Developments in an Integrative Approach of the Psychotherapy of Individuals Suffering from Schizophrenic Symptoms. In E. O’Leary, \& M. Murphy (Eds.), New Approaches to Integrative Psychotherapy (pp. 74-88, Chapter 7). London: Brunner-Roudledge.

Nestoros, J. N. (2012a). Integrative Psychotherapy (Synthetiki Psychotherapia) (2nd Expanded Edition). Athens: Pedio Publications. (In Greek)

Nestoros, J. N. (2012b). In the World of Psychosis (Ston kosmo tis psychosis) (2nd Expanded Edition). Athens: Pedio Publications. (In Greek)

Nestoros, J. N., \& Vallianatou, N. G. (1990). Integrative Psychotherapy (Synthetiki Psychotherapia). Athens: Ellinika Grammata. (In Greek)

Nestoros, J. N., Nair, N. P. V., Pulman, J. R., \& Schwartz, G. (1983). High Doses of Diazepam Improve Neuroleptic-Resistant Chronic Schizophrenic Patients. Psychopharmacology, 81, 42-47. https://doi.org/10.1007/BF00439272

Nestoros, J. N., Patakou-Parassiri, V., Sfakianakis, G., \& Vasdekis, V. G. S. (1998). Clinical Hypnosis in Ancient and Modern Greece. In P. J. Hawkins, \& M. Heap (Eds.), Hypnosis in Europe (pp. 99-117). London: Whurr.

Nestoros, J. N., Suranyi-Cadotte, B. E., Spees, R. C., Schwartz, G., \& Nair, N. P. V. (1982). Diazepam in High Doses Is Effective in Schizophrenia. Progress in Neuro-Psychopharmacology and Biological Psychiatry, 6, 513-516. https://doi.org/10.1016/S0278-5846(82)80141-3

Nestoros, J. N., Vakonaki, E., Tzatzarakis, M. N., Alegakis, A., Skondras, M. D., \& Tsatsakis, A. M. (2017). Long Lasting Effects of Chronic Heavy Cannabis Abuse. American Journal of Addiction, 26, 335-342. https://doi.org/10.1111/ajad.12529

Nestoros, J. N., Zgantzouri, K. A., \& Polemikos, N. (2006). Integrating the Perspectives of Different Mental Health Professionals: An Example of the Benefits of the Collaboration of a Psychologist with a Psychiatrist. In E. O’Leary, \& M. Murphy (Eds.), New Approaches to Integrative Psychotherapy (pp. 105-115, Chapter 9). London: BrunnerRoudledge.

Nestoros, J., Seliniotaki, T., Vergoti, A., \& Benioudakis, M. (2016). Interrelating within 
the Families of Schizophrenics before Their First Psychotic Episode. In J. Birtchnell, M. Newberry, \& A. Kalaitzaki (Eds), Relating Theory: Clinical, Forensic and Other Applications (Chapter 15, pp. 210-226). London: Palgrave MacMillan.

https://doi.org/10.1057/978-1-137-50459-3_15

Norcross, J. C. (1986a). Eclectic Psychotherapy: An Introduction and Overview. In J. C. Norcross (Ed.), Handbook of Eclectic Psychotherapy (pp. 3-24). New York, NY: Brunner/Mazel.

Norcross, J. C. (2005). A Primer on Psychotherapy Integration. In J. C. Norcross, \& M. R. Goldfried (Eds.), Handbook of Psychotherapy Integration (2nd ed., pp. 3-23). New York, NY: Oxford.

Norcross, J. C. (2011). Psychotherapy Relationships that Work: Evidence-Based Responsiveness. Oxford: Oxford University Press. https://doi.org/10.1093/acprof:oso/9780199737208.001.0001

Norcross, J. C., \& Grencavage, L. M. (1989). Eclecticism and Integration in Counseling and Psychotherapy: Major Themes and Obstacles. British Journal of Guidance and Counselling, 17, 227-247.

Norcross, J. C., \& Newman, C. F. (1992). Psychotherapy Integration: Setting the Context. In J. C. Norcross, \& M. R. Goldfried (Eds.), Handbook of Psychotherapy Integration (pp. 3-45). New York, NY, US: Basic Books.

Panaretou, A. P. (2003). Hellas through the Ages. Athens: Ephesus Publications.

Paraskevopoulos, J. (1988). Clinical Psychology. Athens.

Pascual-Marqui, R. D. (2002). Standardized Low Resolution Brain Electromagnetic Tomography (sLORETA), Technical Details. Methods \& Findings in Experimental \& Clinical Pharmacology, 24D, 5-12.

Pascual-Marqui, R. D. (2007). Discrete, 3D Distributed Linear Imaging Methods of Electric Neuronal Activity. Part 1: Exact, Zero Error Localization. The KEY Institute for Brain-Mind Research, University Hospital of Psychiatry. http://arxiv.org/pdf/0710.3341

Pascual-Marqui, R. D., \& Biscay-Lirio, R. J. (2011). Interaction Patterns of Brain Activity across Space, Time and Frequency. Part I: Methods. The KEY Institute for Brain.

Pascual-Marqui, R. D., Esslen, M., Kochi, K., \& Lehmann, D. (2002). Functional Mapping of Electric Neuronal Activity with Zero Localization Error: Standardized Low Resolution Brain Electromagnetic Tomography (sLORETA). In the 8th International Conference on Functional Mapping of the Human Brain.

Pauly-Wissowa, R. E. (1931). Melampus. Argolica, 29, 392-399.

Plevris, C. (1999). Greek Philosophers. Athens: Efstathiades Group A.E.

Plutarch (1973). The Age of Alexander (Translated and Annotated by Ian Scott-Kilvort). London: Penguin Classics.

Polin, A. T. (1959). The Effects of Flooding and Physical Suppression as Extinction Techniques on an Anxiety-Motivated Avoidance Locomotor Response. Journal of Psychology, 47, 235-245. https://doi.org/10.1080/00223980.1959.9916325

Schedlowski, M., Enck, P., Rief, W., Bingel, U., \& Michel, M. C. (2015). Neuro-Bio-Behavioral Mechanisms of Placebo and Nocebo Responses: Implications for Clinical Trials and Clinical Practice. Pharmacological Reviews, 67, 697-730.

https://doi.org/10.1124/pr.114.009423

Schmorrow, D., John, St. M., Kobus, D. A., \& Morrison, J. G. (2004). Overview of the DARPA Augmented Cognition Technical Integration Experiment. International Journal of Human-Computer Interaction, 17, 131-149.

https://doi.org/10.1207/s15327590ijhc1702_2 
Skinner, B. F. (1971). Beyond Freedom and Dignity. New York, NY: Knopf.

Smith, V. A. (1980). Patient Contacts outside Therapy. Canadian Journal of Psychiatry, 25, 297-302. https://doi.org/10.1177/070674378002500404

Sonne, J., Meyer, C. B., Borys, D., \& Marshall, V. (1985). Clients Reactions to Sexual Intimacy in Therapy. American Journal of Orthopsychiatry, 55, 183-189. https://doi.org/10.1111/j.1939-0025.1985.tb03432.x

Sourkes, T. L., \& Pinard, G. (1994). Building on a Proud Past: 50 Years of Psychiatry at McGill. G. Letourneau, Productions Immedia, Outremont, Quebec.

Strupp, H. H. (1983). Psychotherapy: Clinical, Research and Theoretical Issues. New York, NY: Jason Aronson.

Thompson, T., Steffert, T., Ros, T., Leach, J., \& Gruzelier, J. (2008). EEG Applications for Sport and Performance. Methods, 45, 279-288.

https://doi.org/10.1016/j.ymeth.2008.07.006

Truax, C. B., \& Carkhuff, R. R. (1967). Toward Effective Counseling and Psychotherapy: Training and Practice. New York, NY: Aldine.

Van Tubergen, A., \& Van der Linden, S. (2002). A Brief History of Spa Therapy. Annals of the Rheumatic Diseases, 61, 273-275. https://doi.org/10.1136/ard.61.3.273

Veith, I. (1975). The Far East. In J. G. Howells (Ed.), World History of Psychiatry (pp. 662-703). New York, NY: Brunner/Mazel.

Venkoba Rao, A. (1975). India. In J. G. Howells (Ed.), World History of Psychiatry (pp. 624-649). New York, NY: Brunner/Mazel.

Von Bertalanffy, L. (1929). Kritische Theorie der Formbildung (Translated by J. H. Woodger as Modern Theories of Development: An Introduction to Theoretical Biology. Oxford: Clarendon Press, 1933). Berlin: Gebrüder Borntraeger.

Wachtel, P. L. (1977). Psychoanalysis and Behavior Therapy: Toward an Integration. New York, NY: Basic Books.

Walch, J. M., Rabin, B. S., Day, R., Williams, J. N., Choi, K., \& Kang, J. D. (2005). The Effect of Sunlight on Postoperative Analgesic Medication Use: A Prospective Study of Patients Undergoing Spinal Surgery. Psychosomatic Medicine, 67, 156-163. https://doi.org/10.1097/01.psy.0000149258.42508.70

Watson, J. B. (1924). Behaviorism. New York, NY: Norton.

Whitfield, M. D. (1980). Emotional Stresses on the Psychotherapist. Canadian Journal of Psychiatry, 25, 292-296. https://doi.org/10.1177/070674378002500403

Wolpe, J. (1958). Psychotherapy by Reciprocal Inhibition. Stanford, CA: Stanford University Press.

Xygalatas, D. (2011). Ethnography, Historiography, and the Making of History in the Tradition of the Anastenaria. History and Anthropology, 22, 57-74. https://doi.org/10.1080/02757206.2011.546855

Yapizakis, C. (2009). Hippocrates of Kos, the Father of Clinical Medicine, and Asclepiades of Bithynia, the Father of Molecular Medicine. Review. In Vivo, 23, 507-514.

Zeller, E., \& Nestle, W. (1941/1994). History of Greek Philosophy (13th German Edition, Translated into Greek by H. Theodorides, pp. 314-338).

Zgantzouri, K. A., \& Nestoros, J. N. (2017). Psychotherapy Process Research in Schizophrenia Paranoid Type: The Investigation of Delusion Formation through the Evaluation of In-Session Events (Research Article). International Journal of Psychiatry, 2, $1-14$.

Zgantzouri, K. A., Vallianatou, N. G., \& Nestoros, J. N. (2006). Pre- and Post-Session 
Ratings in Integrative Psychotherapy of Schizophrenia: A Way to Better Understand the Mechanisms of In-Session Psychotherapeutic Change? Psychotherapy Research, 16, 201-213. https://doi.org/10.1080/10503300500268060

Zijlstra, T. R., van de Laar, M. A. F. J., Bernelot, M. H. J., Taal, E., Zakraoui, L., \& Rasker, J. J. (2005). Spa Treatment for Primary Fibromyalgia Syndrome a Combination of Thalassotherapy, Exercise and Patient Education Improves Symptoms and Quality of Life. Rheumatology, 44, 539-546. https://doi.org/10.1093/rheumatology/keh537

Zubieta, J. K., \& Stohler, C. S. (2009). Neurobiological Mechanisms of Placebo Responses. Annals of the New York Academy of Sciences, 1156, 198-210.

https://doi.org/10.1111/j.1749-6632.2009.04424.x 